\title{
EUCHARISTIC TRANSFORMATION. THOMAS AQUINAS' ADORO TE DEVOTE
}

\author{
HENK J. M. SCHOOT* \\ Tilburg University
}

\begin{abstract}
Originally the Adoro te devote was not a liturgical hymn but a prayer, probably intended by Thomas Aquinas for personal use when attending mass. Quoting the at present most reliable version of the poem, the author studies Adoro te devote from the angle of transformation: poetic, Eucharistic and mystic or eschatological transformation. Structure and form are analysed, and a number of themes discussed: two alternative interpretations of adoration, several concepts of truth intended in the poem, the good thief and doubting Thomas as symbols of moral and spiritual imperfection, and (present and future) living in connection, in union with God.
\end{abstract}

KEY WORDS: Eucharist, poetry, Thomas Aquinas, systematic Theology, liturgy

The celebration of the Eucharist is the fundamental form of ritual initiation and ongoing transformation in the Catholic tradition. The Eucharist is one of the sacraments of initiation, together with baptism and confirmation, because there is always a first time when someone participates in the celebration of the Eucharist, and also because this always requires a certain amount of preparatory formation. Moreover, from the early Middle Ages onwards, the faithful confess their sins during the celebration of the Eucharist, and thus transform their moral lives. Above all, the celebration of the Eucharist is the primordial form of ongoing transformation, because in the eucharistic prayer the faithful gathered together pray through the words of the celebrant for the activity of the Holy Spirit, so that all who participate may themselves be truly transformed into the body of Christ. The consecration of bread and wine, which makes the body and blood of Christ to be present, is a ritualisation of the transformation of the community gathered together, and of each member of that community individually.

If we were to find a poem that centres on this ritual transformation, we would be at the very heart of what might be called transformative poetry. In

* HENK J. M. SCHOOT (PhD 1993, Catholic Theological University of Utrecht) is associate professor of systematic theology as well as director of the Thomas Instituut te Utrecht at Tilburg University. Email: h.j.m.schoot@tilburguniversity.edu. 
fact, such a poem does exist. It is a text known to and loved by tradition under a title derived from its first words: Adoro te devote ('you I adore devoutly') ${ }^{1}$ and was composed by Thomas Aquinas (c. 1226-1274), the doctor eucharisticus. ${ }^{2}$ It has recently been argued on good grounds that the first words should be changed to Te devote laudo, 'you I praise devoutly'. It is a prayer addressed to Jesus, under the veil of the consecrated elements of bread and wine:

1 Te deuote laudo, latens ueritas ${ }^{3}$,

2 Te que sub his formis uere latitas.

3 Tibi se cor meum totum subicit,

4 Quia te contemplans totum deficit.

5 Visus, tactus, gustus in te fallitur, 6 Sed auditu solo tute creditur.

7 Credo quicquid dixit dei filius,

$8 \quad$ Nichil ueritatis uerbo uerius.

9 In cruce latebat sola deitas,

10 Sed hic latet simul et humanitas.

11 Ambo uere credens atque confitens,

12 Peto quod petiuit latro penitens.

13 Plagas sicut Thomas non intueor,

14 Deum tamen meum te confiteor.

15 Fac me tibi semper magis credere,

16 In te spem habere, te diligere.

17 O memoriale mortis domini,

18 panis uiuus uitam prestans homini.

19 Presta michi semper de te uiuere,

20 Et te michi semper dulce sapere.

21 Pie pellicane, Ihesu domine,

22 Me immundum munda tuo sanguine.
You I praise devoutly, Truth that hides,

You who are truly there, hidden beneath these forms.

To You my heart submits itself completely, because in contemplating You it entirely falls short:

sight, touch, taste, all fail in You;

only by hearing is it all believed.

I believe what the Son of God said:

nothing is more true than the Word of truth.

On the cross was hidden the divinity alone, but here at the same time hides the humanity.

Truly believing and professing both, I plead for what the good thief pleaded. Like Thomas, I do not see the wounds, nevertheless I confess that you are my God.

Make me believe in You,

hope in You, love You always more. O memorial of the death of the Lord, living bread giving life to man, make me always live through you, and to savour your sweetness always. Kind pelican, Jesus Lord,

Purify impure me by your blood,

Wielockx (2007) proposed a new wording of the first verse. That the words Adoro te devote do not belong to this prayer can be deduced from the fact that it has seven rather than the required six syllables, that the stress is not on the first, third, and fifth syllables but on the second, fourth, and sixth, and that it begins with a verb in the first person singular, which is very unusual. These difficulties disappear if the first line is rendered as Te devote laudo.

2 For further details, see Pope Pius XI's proposal to designate Thomas Aquinas as doctor eucharisticus (Moons 2009: 110).

3 The classic version of the poem has deitas rather than veritas. However, veritas is probably original, and it contributes to the poem's focus on the Eucharist as the sacrament of truth. See also the beautiful chiasm latens veritas-vere latitas. Robert Wielockx published a new critical edition of the text in 1998 which we have followed here (Wielockx 1998). Enrique Alarcon's authoritative website www.corpusthomisticum.org has adopted this version, and so have we in this article. The English translation is a slightly adapted version of the one in Venard (2015: 75-76). 


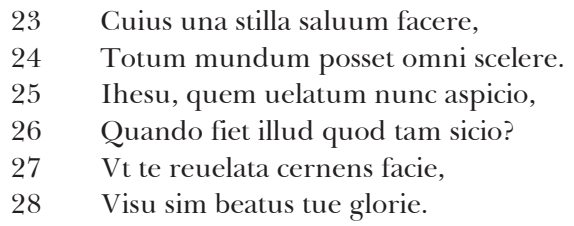

of which one drop could save the entire world from every sin. Jesus whom I now see veiled, when will that which I thirst for come? When, discovering you with unveiled face, will I be blessed by the vision of your glory.

\section{Historical Context}

Thomas Aquinas is almost certainly the author of Adoro te devote. ${ }^{4}$ As a medieval theologian, Thomas is best known to our time as the author of the Summa Theologiae, a work whose focus on interpretation and systematic argument has rarely enraptured the hearts of poets. In his early work, Thomas in fact made some disparaging comments on the possible importance of poetry to the science of theology. On the other hand, however, he wrote an important commentary on part of the Psalms, and he is regarded by many as the author of the liturgy for Corpus Christi, including beautiful hymns such as Sacris solemniis and Pange lingua. The Adoro te is usually also associated with these texts, but this is not historically correct. The Adoro te is not part of the Corpus Christi liturgy. It is known to us as a hymn, but the text was not set to music until the eighteenth century. It was originally a prayer, written by Thomas for his own use, perhaps in 1264. Thomas, a Dominican friar and a priest, not only said mass himself every day, but was also accustomed to attend a second mass. It was for his own use during this second mass that he composed this text. This explains why it is not written in the first person plural, as is usual for hymns, but in the first person singular.

\section{Structure and Form}

The poem consists of fourteen distichs or two-line verses. Each line itself consists of two half-verses, the first half of which has six (hexameter) syllables and the second has five (hexameter) syllables. The only exception is the first halfverse Adoro te devote, which consists not of six, but of seven syllables. It is not correct to arrange the fourteen distichs in seven stanzas of four lines each, an arrangement that only became customary after the prayer started to be used as a hymn. It is not supported by the oldest manuscripts. 
The lines have end rhyme in pairs. The first seven distichs each end on words ending on a consonant, while the last seven distichs have end words with a vowel. This creates a clear structure of two halves, each consisting of fourteen lines.

The form of the poem therefore draws attention to the transition from the first half to the second half. The transition that is expressed there, the transformation, is the transition from prayerful contemplation of the truth of the hidden God, to a petitionary prayer addressed to the same Jesus. The imperative dominates in the second half of the poem: make me believe, hope, love; give me life, make me savour; purify me; quench my thirst for you. The form of the poem thus reflects the content: a prayer for ongoing (more, verse 15) transformation that corresponds to the transformation of bread and wine. ${ }^{5}$

Thorough analysis of other poetic characteristics has caused Wielockx to propose a new arrangement of the distichs, a somewhat odd one at first sight. Both parts of the poem conclude with a group of two distichs. Moreover, the first half has a group of three distichs. This arrangement is based on the end rhyme on '-itas' in the verses 1-2 and 9-10 and on '-ere' in 15-16, 19-20 and 23-24, and is confirmed by the specific vocabulary used. In this way, an arrangement emerges based on 'inclusion with simultaneous exclusion' (Wielockx 1998: 159). Verses 3-8 are part of the inclusion, and so are 17-18 and 21-22, while verses 11-14 and 25-28 are excluded. This analysis draws attention to the sections that are part of the inclusion: 3-8 is about viewing, perceiving and believing Christ's hidden presence, while verses 17-18 and 21-22 draw attention to the consecrated elements, first bread and then wine.

\section{Themes}

Adoration and Praise. The liturgical practice that we know as 'adoration', adoration of the Blessed Sacrament, received its name from the Adoro te. This kind of adoration takes place firstly during the celebration of the Eucharist, after the consecration. In the Middle Ages, the elevation or elevatio of the consecrated host and (later) of the chalice containing the consecrated wine became increasingly important. The priest stood with his back to the people during the consecration, which means that the faithful were not able to follow the Eucharistic prayer that he was pronouncing because they could not hear or understand the priest. They could recognise the elevatio, however, and for some of the faithful this became the start of an individual, more personal

Of course Thomas would not speak of transformation, but of transubstantiation. The elements of bread and wine do not change, but their essence or substance. The twofold structure, where the second part bears the character of a petitionary prayer, can also be discerned in Thomas' eucharistic hymns, according to Murray (2013: 252). 
bond of prayer with the Risen Lord. ${ }^{6}$ Jesus' coming under the veil of bread and wine invites a prayerful answer, in which the believer responds in a spiritual way to the offer of communion with him. This is sometimes called 'spiritual communion', as distinct from the actual reception of communion. Of course the two practices are not mutually exclusive.

This liturgical practice was subsequently also performed outside the context of the celebration of the Eucharist as such. This still happens, for instance after the celebration of the Lord's Supper on Holy Thursday, when adoration takes place at the altar of repose, or on other occasions during the exposition (expositio) of the Blessed Sacrament in a monstrance. And the monstrance is sometimes carried along in procession, permitting the faithful to adore the Blessed Sacrament.

As has been seen, the liturgical practice is called after the Adoro te. But how can adoration be interpreted theologically? The poem gives us two key terms that can be used for this in its third and fourth line: to submit and to fall short, 'to You my heart submits itself completely, because in contemplating You it entirely falls short'. In Thomas Aquinas' view, every human being is obliged to fulfil a religious duty. Every human being must honour God, pray to him, and must be conscious of the infinite distance between Creator and creature. For Thomas this is a reality that is expressed in the virtue of religio, the service of God. Every human being is obliged to serve God, just as subjects are obliged to honour the king, to whom they owe so much. Subjects kneel in the presence of the king, and they also kneel when the Heavenly King is manifested. This theological interpretation does not perhaps seem very plausible anymore in our own time. Nonetheless it is still a meaningful interpretation of adoration, because it renders honour to the Giver of life and of everything that is good.

The Adoro te, however, contains a second interpretation of adoration. This second interpretation is more difficult to identify, but it runs through all of 
the other stanzas. The entire poem culminates in one central theme, which is prepared in all of the stanzas: eschatological communion with Christ. The whole poem furthers the desire of the eschatological vision, face to face, of Jesus, and of the happiness that this brings. The verses work towards this climax by prayerfully evoking several figures of Jesus. It begins in the first verses with the eucharistic figure in the elements of bread and wine, but the subsequent verses successively refer to Jesus as Word, as the Crucified One, as the risen Lord, as the Bread of Life, which is a reprise of the first verses, and, finally, as Pelican or Redeemer. Each stanza focuses on another aspect of communio with Christ, and each aspect gives further focus to and builds up adoration. Adoration takes form when the adorer listens to the Word, meditates on the cross, encounters the risen Lord, approaches the sacrament of the Eucharist and experiences the forgiveness of sins.

In this manner the rest of the prayer supplements the more external interpretation of the concept of 'adoration', through the key concepts of 'to submit' and 'to fall short', by providing a much more important interior interpretation: communion with all of the figures of Jesus known to the believer. Adoration consists of confessing your faith in these figures of Jesus.

All this can be further clarified by looking at the posture of the believer during adoration. It is a basic Christian conviction that the posture of the believer during the liturgy is an external sign of his interior disposition. The Council of Nicaea determined in 325 that the Christian's posture should be conformed to the figure of Christ (Radle 2016). Canon 20 prohibits the faithful from kneeling during the celebration of the Eucharist on Sundays and during Eastertide, because during those times they should give expression to their union with the risen Lord, and this can be done by standing up rather than by kneeling. This canon has gradually fallen into desuetude in the Western church. In fact, it was probably precisely the influence of Eucharistic devotion that stimulated the custom of kneeling during the most important moments in or outside the celebration of the Eucharist. This posture can be explained on the basis of the first interpretation of adoration proposed above: to submit and to fall short. But the posture of kneeling can also be explained on the basis of Christ's becoming man and taking the form of a servant. When Jesus washed Peter's feet at the Last Supper, he knelt before him. This was an external sign of his work of service and of his love. Peter resisted it, because he was inclined to interpret adoration in the first way: giving his Lord the honour he was due. But Jesus shows that there is a second interpretation, a more important one, which makes it possible to regard kneeling as communion with Christ's work of service and love. This last interpretation is the interpretation proposed by Adoro te, as is demonstrated by the adoration of both the Crucified One and the Pelican who is willing to give of his own blood. 
Truth that Hides. A crucial theme of this prayer is mentioned in its very first line in the words 'truth that hides'. The truth that 'hides' (verse 2), 'here' (verse 10) and 'now' (verse 25), beneath 'these forms' (verse 2) - the context is clear-is Christ. Christ is the truth itself, in the words of John the Evangelist (14:6), and he can therefore be addressed by the name of 'truth'. The prayer also mentions 'truth', because Thomas regards the Eucharist as the sacrament of truth. A recurring theme in his theology of the Eucharist is the antithesis between deception and fiction on the one hand and truth on the other. There is no deception or fiction in this sacrament, Christ is truly present. But 'truly' in what sense? To the mind, to the senses, to faith? The first inclusion of 3 distichs (verses 3-8) answers this question. The combination of 'heart' and 'contemplation' in verses 3 and 4 points to something that is characteristic for Thomas' entire oeuvre, i.e. that cor ('heart') stands for a much wider concept than simply heart or feeling: it stands for all of man's higher spiritual faculties Christ is hidden to the intellectual faculty; this faculty cannot recognise him. The senses fail as well. It is not that they are misled, as some translators have erroneously rendered fallitur, but that the senses of vision, taste and touch cannot recognise Christ's presence. ${ }^{7}$ Nor, obviously, can the sense of hearing, so when the prayer continues to assert that belief rests safely only 'on hearing', we must conclude that 'hearing' is used here as a metaphor, as Paul does in his Epistle to the Romans (10:17). 'Hearing' stands for accepting truth on the basis of authority, for believing the words another person speaks. He who prays cannot himself understand or perceive Christ's presence, but he rests on the authority of the words that are spoken to him. And the words in question are words proclaimed or spoken by the Son of God. His word is the word of Truth, nothing is truer than these words. The words spoken by the Son of God are the words of the institution of the Eucharist: 'This is my body. This is my blood'. And these words are true.

This brings to light a second layer of the meaning of truth. The truth at issue here is not only the truth of believing that bread and wine are changed into the body and blood of Christ. It is also the truth of the language that Christ speaks. Should Christ's words be interpreted in a symbolic way, or should bread and wine be interpreted as mere signs of Christ in his passion? Thomas categorically rejects these two views. ${ }^{8}$ But in interpreting the words of institution, he also contends that the truth at issue is practical truth. $\mathrm{He}$ ment against recognising the Adoro te as authentic, as Thomas regularly and explicitly states that the senses cannot err in what is their proper object. This reveals the weakness of this argument: the hidden humanity of Christ in the consecrated species is not the proper object of the senses. Wielockx (1998: 158) has convincingly rebutted this criticism. Summa Theologiae III, 75, 1. All of Thomas' works can be found on www.corpusthomisticum.org. 
uses the image of an artist who has a particular design in mind and faithfully realises that design. There is a relation of practical truth between the design and the work of art. These words of Christ should be regarded in the same way; they are true also in this sense. ${ }^{9}$ Moreover, Thomas says here: 'the word of God is related in this manner to the things made by the word'. The truth that is at issue here is the truth of the practical, creative intellect. In this way, he thematises creation as such, creation which was made and is sustained 'by the word', i.e. by Christ as the word of God. The conviction that Thomas expresses here about the truth hidden in this sacrament goes far beyond the Eucharist as such. All of created reality is a form of practical truth, i.e. when it is traced back to the word of God. And it is this word which comes to be present in a special manner in the sacrament of the Eucharist.

This conception of the truth also applies to the poem. The poem underlines the truth of the Eucharist, is itself a work of art, and effects what it signifies, i.e. the transformation of the person who prays it. This kind of truth can be predicated of the work of art, because the believer has a fundamental belief in the true relation between word and reality. Because the word of God has truly created our reality, our words can truly signify our reality. Signify, and sometimes create. ${ }^{10}$

The Thieves and the Doubting One. Besides Jesus, the prayer mentions two other people from the gospels: one of the two thieves crucified together with Jesus, and the Apostle Thomas, the doubting one. Luke (23:39-43) recounts how one of the thieves rebuked the other after the latter mocked Jesus. He then asked Jesus to remember him when he came into his kingdom. Jesus replied: 'In truth I tell you, today you will be with me in paradise.'

The poet makes the thief's prayer his own and asks Jesus to grant him what he granted the thief. In doing so, this verse anticipates the last verses, where the petition to be finally united ('face to face', 1 Corinthians 13:12) to Jesus is the central focus.

The other biblical person is the 'doubting' Thomas, Aquinas' patron saint, with whom perhaps he identified personally. John writes of him (20:24-39) that he was not present when the risen Lord first appeared to the disciples. Thomas did not believe it and said that he would only trust his own eyes and

Summa Theologiae III, 78, 5 corpus: ‘... haec locutio habet virtutem factivam conversionis panis in corpus Christi. Et ideo comparatur ad alias locutiones quae habent solum vim significativam et non factivam, sicut comparatur conceptio intellectus practici quae est factiva rei, conceptioni intellectus nostri speculativi, quae est accepta a rebus (...) sic enim se habet verbum Dei ad res factas per verbum'.

10 Cf. Venard (2015: 71-74); Venard (2009: 649). Tück (2014: 311) points to another aspect that is related to truth: the believer's adoration is directed not so much to that which mediates Christ, but to Christ himself.

PERICHORESIS 14.2 (2016) 
hands; he would believe that the Lord was alive only if he could see and touch his wounds. When Jesus appeared for the second time, he spoke to Thomas, and the last words he said to him were: 'Blessed are those who have not seen and yet believe'.

Aquinas unites his prayer with Thomas's, who ultimately confessed Jesus as 'my Lord, my God'. Incidentally, in his commentary on the Gospel of John, Aquinas remarks that these words show that the biblical Thomas instantly became a good theologian-giving them yet another thing in common. ${ }^{11}$ But Aquinas also makes Jesus' last words his own: believing without seeing. I do not see, but I believe in you as my God. The reference to the Apostle Thomas thus concludes the theme of the first part of the prayer, which deals with the inadequacy of the intellectual and sensory faculties. Faith does not rest on the senses, but on the word of the Lord; hidden to the intellect and to the senses, but recognisable to faith.

The thief and Thomas each symbolise an essential form of imperfection: one of the moral life and the other of the spiritual life. Both imperfections make up the state of mind of the person who prays to Jesus, and form part of his prayer: I am falling short, purify me, redeem me.

Living in Connection. The second part of the poem is a petitionary prayer. 'I plead' appears once at the end of the first part, in relation to the penitent thief, but it appears very much in the context of the suffering and risen Lord. Christ who is now present under the elements of bread and wine, leads the person praying this prayer back to where it all began, to the foundation of Christian life: the passion, death and resurrection of the Lord. For the person who binds himself to Christ, who answers the call to accompany him, life is a life of faith, hope, and charity. But the theological virtues, good dispositions of the human spirit, are not of human making; nor are they human possessions. God gives the believer these virtues and they can just as easily be lost when the believer turns away from God in word and/or deed. This is why the person who prays asks to grow in faith, hope, and charity: he who is permitted to grow in these virtues will increase in the ability to resist the things that lead away from God.

This petition is supported by forms of poetic expression: the prayer mentions semper ('always') three times, and 'making' or 'giving' three times. In addition, there is a chiasm between me tibi semper (verse 15) and te michi semper 
(verse 20). Another striking feature is that a form of life is mentioned up to three times: 'living' (vivus, verse 18), 'life' (vita, verse 18) and 'live' (vivere, verse 19$).{ }^{12}$

This life of faith, hope, and charity is a life 'through you' (verse 19), i.e. a life that is nourished by the living bread, and purified through the blood of Christ. The two elements that are part of the inclusion in this second part are dedicated to the bread (verses 17-18) and the wine (verses 21-22) respectively. Joys and sorrows are shared, and the passage te michi semper (dulce sapere) (verse 20), which is situated exactly in the middle, makes this clear in a very particular way. This passage can be read as an allusion to Hosea 2:19-20, where the Vulgate has te michi three times, the first time followed by in sempiternum; God says 'I will make you to be my wife for ever'. Thomas is the only one of his contemporaries to interpret these words as referring to the covenant between God and his faithful. Jean-Pierre Torrell has drawn attention to this and has added that this also places Thomas in the mystical tradition (Torrell 2000: 372). God unites himself to the believer, and this unio, this union is precisely the subject of the prayer; the prayer asks to be permitted to live in union with God for ever.

The purity mentioned in the second section that is part of the inclusion as it addresses the good Pelican, is similar. Poetically, too, the emphasis in verse 22 is on mundus, pure. With your blood, purify me, who am impure, which is reminiscent of one of the beatitudes: 'blessed are the pure in heart, for they shall see God' (Matthew 5:8). The image of the pelican who pricks her own breast to feed her hungry young with her own blood, regarded since the second century as a metaphor for the salvific meaning of Christ's crucifixion, leads to that of the purifying power of this blood. And this purifying function is emphasised very strongly in verses 23 and 24, which Thomas elsewhere attributes to Bernard of Clairvaux (mistakenly as it was Nicholas of Clairvaux $)^{13}$

Bread and wine evoke a deep desire and feed this desire; the desire that the veil that still hides Jesus will be removed, and that the person who is praying may see him face to face. There are three different words for seeing in the four last verses: 'behold' (aspicere), 'see' (cerneo), and 'view' (visus). They express the salvation for which the person who prays is asking. An unexpected but beautiful parallel appears between the two excluded parts (verses 11-14 and 25-28), pivoting on the Apostle Thomas. The words which Jesus spoke to Thomas, not seeing and yet believing, are transformed into: no rhymes with a preceding word: habere, te diligere. 
longer believing, but seeing. When he prays, Thomas Aquinas asks that he made undergo this transformation himself.

\section{Pattern of Transformation}

The pattern of transformation only becomes clear to those who are sensitive to the aesthetic dimension of this prayer. Thomas' view, famously, is that beauty is defined by the three characteristics of integritas, claritas, and proportio (STh I, 39,8 sed contra). If we confine ourselves to the last characteristic for present purposes, then the relation signified by proportion is primarily the relation that exists between the subject of the person who prays and the object of the work of art, the poem. And as the poem explicitly addresses the Lord hidden in the Sacrament, the Lord is emphatically part of the object itself. Given this, the beauty of the poem urges the reader to focus on the relation that exists between subject and object, or, more accurately perhaps, between the (praying) subject and the subject of adoration. The pattern that emerges, is the pattern of a dialogue between 'You' and 'I'. The praying 'I' responds to the coming of 'You' under the elements of bread and wine. The praying 'I' responds with adoration, i.e. with the required act of praise that consists of expressing faith in 'You'. On the one hand, faith in 'You' is expressed by articulating the actions that the praying 'I' performs: submitting, falling short, believing, confessing, being remorseful, seeing and confessing. On the other hand, this faith is expressed when the person who is praying states the object of his faith: hidden deity, hidden humanity. The entire focus of the first part of the prayer is on faith in the truth which manifests itself in the sacrament of the Eucharist.

The dynamic of transformation becomes particularly clear in the second half of the prayer, where faith, hope, and charity are called down upon the I's past, present, and future. The prospect of the future opens up through commemoration of the Lord's passion, so that the knowledge of being set free from sin makes bliss possible. Seeing face to face, other than in the context of the celebration of the Eucharist, this ultimately is beatitude; and a perspective on it is already opened to the person who prays in the here and now. It is the perspective which transforms him.

\section{Poetic Transformation}

The Adoro te prayer was written in the form of a poem. It is worthwhile at the end of this article to reflect on this fact itself, beyond the details of its poetic form. The prayer is a poem, and as a poem it is a work of art. Specifically, it is a work of art that consists of language. It is therefore also a work of art that can be read, spoken and sung, time and again. This can be done, prayerfully, during the celebration of the Eucharist, and as a prayer, it then becomes a response to the living Lord who comes to be present in the elements of bread 
and wine during that celebration. In this context of the celebration of the Eucharist, the prayer obtains the meaning that underlies it: its literal meaning.

The speaking of the words of institution is often regarded from the perspective of certain concepts from linguistic philosophy. Language not only has a referential function; it is also expressive, and can furthermore sometimes be performative. You can use language to perform speech acts (J. L. Austin). The clearest example of this is when you make a promise: you make a promise by saying that you are making a promise. The words of institution can be compared to a performative speech act: pronouncing these words obtains a power given by Christ, changing bread and wine into the body and blood of Christ. Associating this priestly act with a performative speech act does not prove or explain the transformation of bread and wine; it merely shows that language is capable of doing more than we think. Language is not only referential, but can also manifest that which it signifies. An unexpected relation of truth emerges between the act of speaking and the gifts of bread and wine: a relation of practical truth. Speaking creates a new reality.

This approach to the Eucharist can also give praying the Adoro te a new meaning. By praying this poem, the believer unites himself to the transformation of bread and wine; his prayer is his response to this transformation, which is thereby transferred to and extended into his life. Not only the Eucharistic prayer, but this prayer of adoration also transcends the words it is composed of and allows Christ to unite himself with the believer. This way, it does what all good art does: it elevates and sublimates the person who contemplates it. Alain Michel and Pascale Borde have written that a work of art is a monstrance which manifests God to the faithful: no longer merely a work of art, but also the object of worship, which gives the worshiper a share in the divine life that is being manifested..$^{14}$

The Adoro te corresponds to Christ's coming under the elements of bread and wine, and thus it is a preparation for communion, union with the body of Christ. ${ }^{15}$ It places all this in an eschatological context. In this manner, the prayer never ceases to aid the transformation of the life of the person who prays it.

\section{Bibliography}

Dankbaar WF (1981) Adoro devote: Lotgevallen van een middeleeuws sacramentslied. Nederlands Theologisch Tijdschrift 35(4): 298-325. riana 6-7 (1987): 5-6.2-11.

15 The decision to include Thomas' prayer in the 1570 Missale Romanum as the prayer of the priest after the celebration of the Eucharist appears questionable from this perspective. This difficulty does not arise for some of the oldest manuscripts which mention that the prayer was said when administering Viaticum. 
Murray P (2013) Aquinas at Prayer: The Bible, Mysticism, and Poetry. London: Bloomsbury.

Radle G (2016) Embodied Eschatology: Canon 20 of Nicaea and Its Reception Across Christian Traditions, part I. Worship 90. (pro manuscripto)

Moons J (2009) Thomas Doctor Eucharisticus? Voorstudie over de samenhang van theologie en liturgie in verband met de eucharistie. In Schoot HJM (ed) Jaarboek 2008 Thomas Instituut te Utrecht. Utrecht: Thomas Instituut, pp. 109-139.

Torrell JP (2000) Adoro Te: La plus belle prière de Saint Thomas. Recherches Thomasiennes: Études revues et augmentées (Bibliothèque thomiste 52). Paris: Vrin.

Thomas Aquinas, Summa Theologiae (STh).

Torrell JP $\left(2015^{3}\left[1993^{1}\right]\right)$ Initiation à Saint Thomas d'Aquin: Sa personne et son cuvre (Vestigia 13). Fribourg: Cerf.

Tück JH (2014) Gabe der Gegenwart: Theologie und Dichtung der Eucharistie bei Thomas von Aquin. Freiburg: Herder.

Venard OT (2009) Pagina sacra: Le passage de l'Écriture saint à l'écriture théologique. Paris: Cerf.

Venard OT (2015) Religious Imagination and Poetic Audacity in Thomas Aquinas. In Bugliani Knox F, Lonsdale D (eds) Poetry and the Religious Imagination: The Power of the Word. Farnham: Ashgate.

Wielockx R (1998) Poetry and Theology in the Adoro te devote: Thomas Aquinas on the Eucharist and Christ's Uniqueness. In Emery K, Wawrykow J (eds) Christ among the Medieval Dominicans: Representations of Christ in the Texts and Images of the Order of Preachers (Notre Dame conferences in medieval studies 7). Notre Dame, IN: University of Notre Dame Press, pp. 157-174.

Wielockx R (2007) Adoro te deuote: Zur Lösung einer alten Crux. Annales theologici: revista internazionale di teologia 21(1): 101-138.

Wilmart A (1932) Auteurs spirituels et textes dévots du moyen age latin, Études d'histoire littéraire (Études et documents pour servir à l'histoire du sentiment religieux). Paris: Bloud et Gay. 